\title{
NASOPHARYNGEAL CARCINOMA. X. PRESENCE OF EPSTEIN-BARR GENOMES IN SEPARATED EPITHELIAL CELLS OF TUMOURS IN PATIENTS FROM SINGAPORE, TUNISIA AND KENYA
}

\begin{abstract}
C. Desgranges ${ }^{1}$, H. Wolf ${ }^{2}$, G. De-Thé ${ }^{1}$, K. Shanmugaratnam ${ }^{3}$, N. Cammoun ${ }^{4}$, R. Ellouz ${ }^{4}$, G. Klein ${ }^{5}$, K. Lennert ${ }^{6}$, N. MuÑoz ${ }^{1}$ and H. zur Hausen ${ }^{2}$

1 International Agency for Research on Cancer (IARC), 150 Cours Albert Thomas, 69008 Lyons, France; ${ }^{2}$ Institut für Klinische Virologie der Universität Erlangen, 852 Erlangen, Loschgestrasse 7, Federal Republic of Germany; ${ }^{3}$ Department of Pathology, University of Singapore, Outram Road, Singapore 3; ${ }^{4}$ Institut Salah Azaiz, Tunis, Tunisia; ${ }^{5}$ Department of Tumour Biology, Karolinska Institutet, Stockholm 60, Sweden; ${ }^{\circ}$ Institut für Pathologie, University of Kiel, Kiel, Federal Republic of Germany.
\end{abstract}

\begin{abstract}
Nasopharyngeal carcinoma (NPC) biopsies from Singapore, Tunisia and Kenya were compared, before and after separation of epithelial and lymphoid cells, for their $E B V-D N A$ content, using the cellular DNA-EBV-cRNA hybridization test. In all instances where successful separation of the two cell types was achieved, epithelial tumour cells showed a higher EBV-DNA content than lymphoid cells or tumour before cell separation. It is, therefore, suggested that EBV-DNA is mostly limited to epithelial cells. No significant difference was observed between NPC tumours originating from various geographical areas.
\end{abstract}

The presence of Epstein-Barr virus (EBV) in nasopharyngeal carcinoma (NPC) has been repeatedly demonstrated by various nucleic-acid hybridization techniques (zur Hausen et al., 1970; Nonoyama et al., 1973; Wolf et al., 1973; zur Hausen et al., 1974; Wolf et al., 1975). Recently, virus-specific nuclear antigens (EBNA) have also been detected by immunofluorescence in NPC biopsies and specifically in the epithelial tumour cells (Wolf et al., 1973; de-Thé et al., 1973a; Huang et al., 1974; Klein et al., 1974).

Taken together with the above, the specific serological response of NPC patients to EBV (reviewed by Klein, 1973 and de-Thé and Geser, 1974) points to a role of EBV in the development of this malignancy.
The aim of the present study was: (1) to compare the EBV DNA content in separated epithelial and lymphoid cell subpopulations from tumour pieces; and (2) to compare NPC biopsies from different geographical areas and ethnic groups for their EBV DNA content.

\section{MATERIAL AND METHODS}

\section{Tumour material}

Biopsies from tumours of the nasopharynx were obtained from three geographical areas as follows: (1) 28 tumours from the Cancer Institute Salah Azaiz, Tunis; (2) 17 tumours from Kenya; (3) 16 tumours from Singapore. Fifteen tumours other than NPC were obtained from these

Received: April 11, 1975. 
different areas and grouped as controls. We are indebted to Dr. Williams (Kuluva Hospital, Arua, Uganda) and Dr. Brubaker (Shirati Hospital, Musoma, Tanzania) for providing Burkitt lymphoma (BL) biopsies tested in the present study.

The histopathological diagnosis of all tumours was obtained from each institute. Upon receipt at IARC, a small piece of each biopsy was processed to evaluate histopathologically the tumour pieces used for DNA extraction.

Biopsies from Tunis arrived in the laboratory within $24 \mathrm{~h}$, and had been kept in RPMI tissue culture medium at 10 to $12^{\circ} \mathrm{C}$ between the time of removal and arrival. Tumours from Kenya were sent in tissue-culture medium at $+4^{\circ} \mathrm{C}$ and arrived usually between 48 and $72 \mathrm{~h}$ after departure. Tumours from Singapore were frozen after removal and sent to Lyons in dry ice.

\section{Separation of epithelial and lymphoid cells from} biopsies

After a small portion had been taken for histopathology as noted above, each tumour was divided into two parts: one was stored at $-70^{\circ} \mathrm{C}$ until DNA extraction, the other was manipulated in tissue-culture medium (RPMI 1640 with 10\% fetal calf serum) with mounted needles so that lymphoid and epithelial cells were liberated into the medium. The degree of dissociation was followed by phase-contrast microscopy and if this dissociation was not complete, separation of clumped cells was achieved by trypsin treatment $\left(0.25 \%\right.$ for $30 \mathrm{~min}$ at $\left.37^{\circ} \mathrm{C}\right)$. After complete

TABLE I

HYBRIDIZATION OF DNA FROM TOTAL TUMOURS AND SEPARATED CELL PREPARATIONS FROM NPC BIOPSIES WITH EBV-cRNA

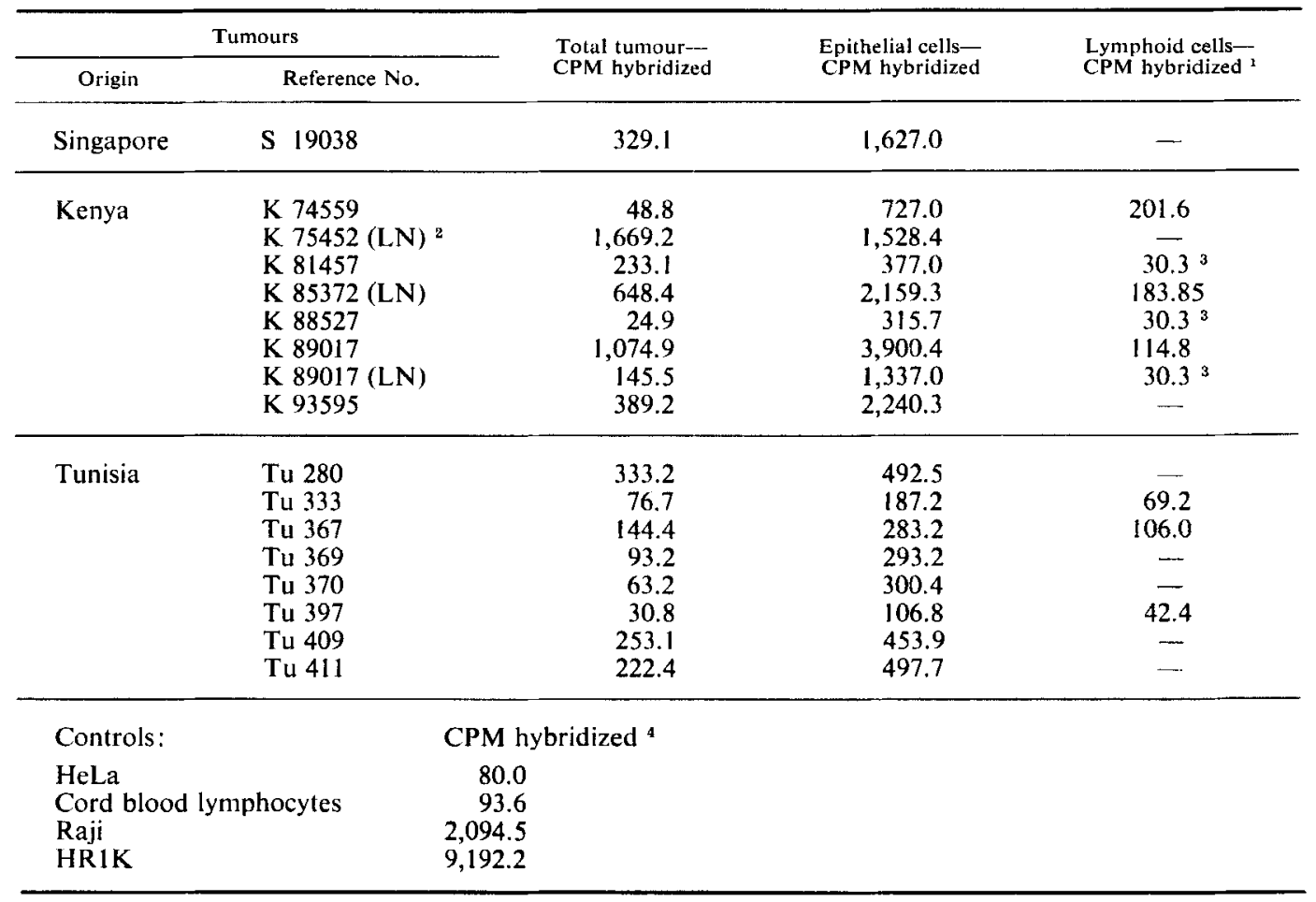

\footnotetext{
${ }^{1}$ Tumours from which less than $50 \mu \mathrm{g}$ of DNA were yielded by lymphoid cell sub-populations.

${ }^{2} \mathrm{LN}=$ cervical lymph-node metastasis.

${ }^{3}$ These three preparations were mixed to obtain $50 \mu \mathrm{g}$ of DNA.

$\checkmark$ Mean of three experiments.
} 
dissociation, the cell suspension was carefully layered on a Radioselectan Ficoll gradient (1 vol of $31 \%$ Radioselectan with 2.4 volumes of $9 \%$ Ficoll solution) as previously described (Yata $e t$ al., 1973). After $30 \mathrm{~min}$ of centrifugation at $400 \times g$, the epithelial cells sedimented to the bottom, whereas the lymphocytes remained on top of the Radioselectan Ficoll layer. The lymphocyte-enriched layer was found to contain more than $90 \%$ lymphocytes whereas the pellet contained approximately $80 \%$ epithelial cells. After removal and washing with PBS, these cell subpopulations were stored at $-70^{\circ} \mathrm{C}$ unt il DNA extraction.

\section{DNA extraction}

DNA extraction was performed from total tumours, and from each separated cell subpopulation, following techniques described previously (zur Hausen and Schulte-Holthausen, 1970; Wolf et al., 1973).

\section{Hybridization with $E B V$-specific cRNA}

EBV-specific cRNA was prepared as previously described (zur Hausen et al., 1972). Fifty $\mu \mathrm{g}$ of DNA from each cell sample were heatdenaturated, bound to nitrocellulose membrane filters and then kept for $4 \mathrm{~h}$ at $80^{\circ} \mathrm{C}$. After addition of 57,000 CPM of denaturated cRNA in a total volume of $1 \mathrm{ml}$ containing $48 \%$ formamide $2.5 \times \mathrm{SSC}$ (sodium chloride, sodium citrate) and $0.05 \%$ SDS (sodium dodecylate sulphate) the filters were incubated for 6 days at $45^{\circ} \mathrm{C}$. After washing with $2 \times \mathrm{SSC}$, filters were treated with RNase $(20 \mu \mathrm{g} / \mathrm{ml})$ for $60 \mathrm{~min}$ at $37^{\circ} \mathrm{C}$, washed again and counted in a Packard liquid spectrometer type 3375 .

\section{EBV serology}

VCA antibody determination was performed with the Jijoye cell line containing approximately $5 \%$ of immunofluorescent cells according to Henle and Henle (1966). Antibodies to EA were determined by using Raji cells 3 days after superinfection with P3HR-1 virus (Henle et al., 1970). Complement-fixing (CF) antibodies were titrated with soluble antigen (S) extracts from the Raji cell line (de-Thé et al., 1973b). Titration of EBNA antibodies on Raji cells followed the techniques described by Reedman and Klein (1973) with minor modifications.

\section{RESULTS}

Table I presents the hybridization data obtained by annealing DNA from separated epithelial and lymphoid cells with EBV-cRNA. On comparison of these data with hybridization rates obtained with DNA from cord blood lymphocytes or HeLa cells, nine out of 17 NPC tumour specimens showed high levels of hybridization with EBVcRNA. DNA from the epithelial cell preparations annealed in 15 out of 17 specimens at significantly higher rates than the DNA from the same total tumour. For some lymphoid subpopulations insufficient DNA was available for hybridization tests. However, in all instances where lymphoid subpopulations were tested, the hybridization rate was always lower than that of corresponding epithelial subpopulations.

Tables II, III and IV show hybridization data obtained from total biopsy for all tumour specimens obtained from each area. In most of the cases, separation of epithelial and lymphoid cells was either not successful or not possible because of the small size of the original biopsy. In these Tables, arranged according to geographical areas, the histopathological characteristics, including the degree of differentiation, the amount of lymphoblastoid infiltration and of stroma, are given together with the EBV serology. The level of hybridization showed great variations within each series of tumours. Eleven out of the 28 specimens from Tunisia, 6 out of the 16 from Singapore and 12 out of the 17 from Kenya revealed significantly elevated annealing rates as compared to the controls.

Table $\mathrm{V}$ gives the results for tumours other than nasopharyngeal carcinoma, but collected from the same geographical areas. In this group of " other tumours" only 2 out of 16 showed significant levels of hybridization, both being from BL cases.

Tables II to $\mathrm{V}$ also reveal the EBV seroreactivity of the corresponding patients. EA antibody titres only appear to correspond to a certain extent to the hybridization data: in Kenyan patients high EA titres corresponded to high annealing rates, while low titres related to low rates; in Tunisian patients with high EA titres no such pattern emerged, whereas patients with low EA titres also had low hybridization rates; in Singapore patients no relationship was apparent. 
DESGRANGES ET AL.

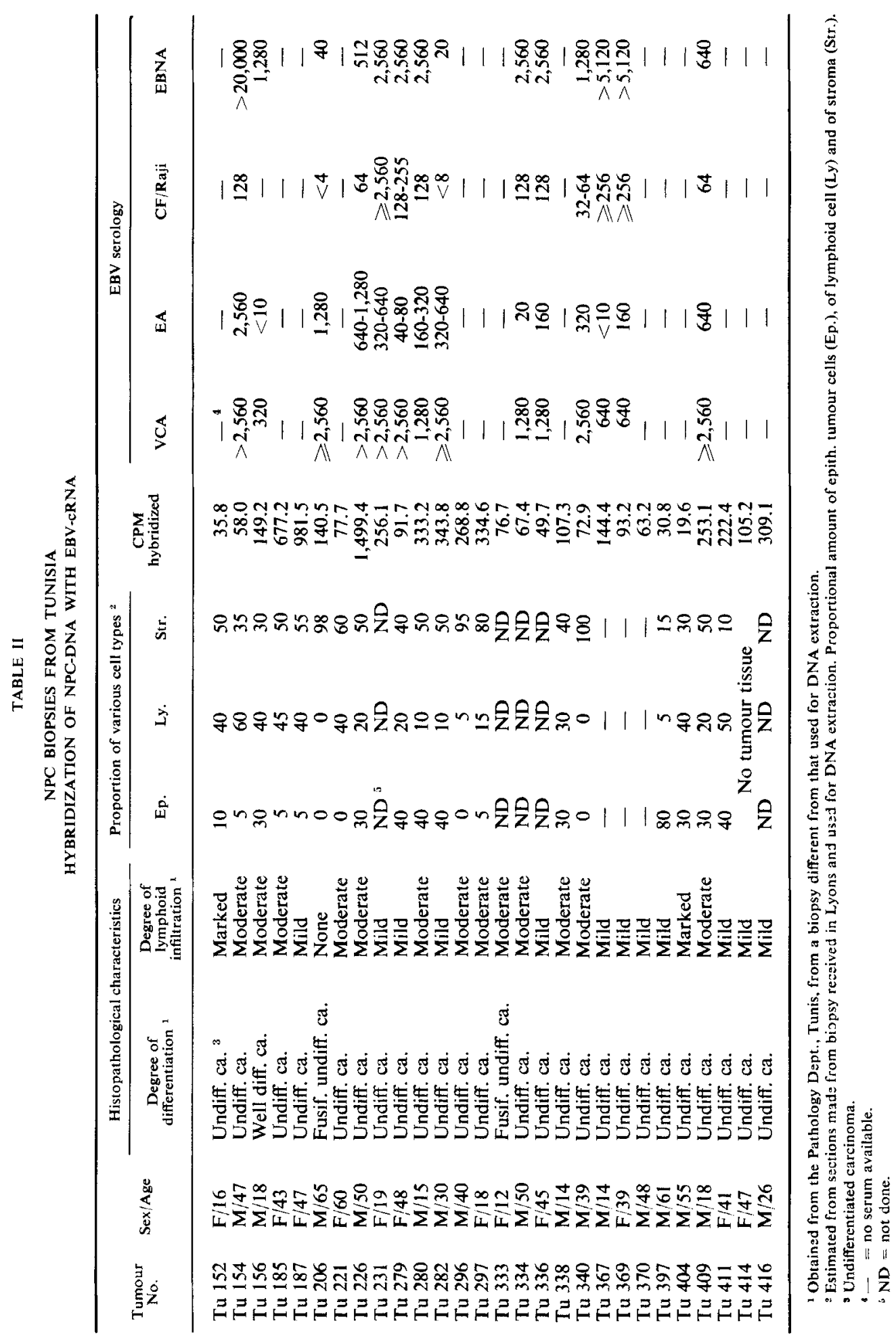


EBV IN NASOPHARYNGEAL CARCINOMA

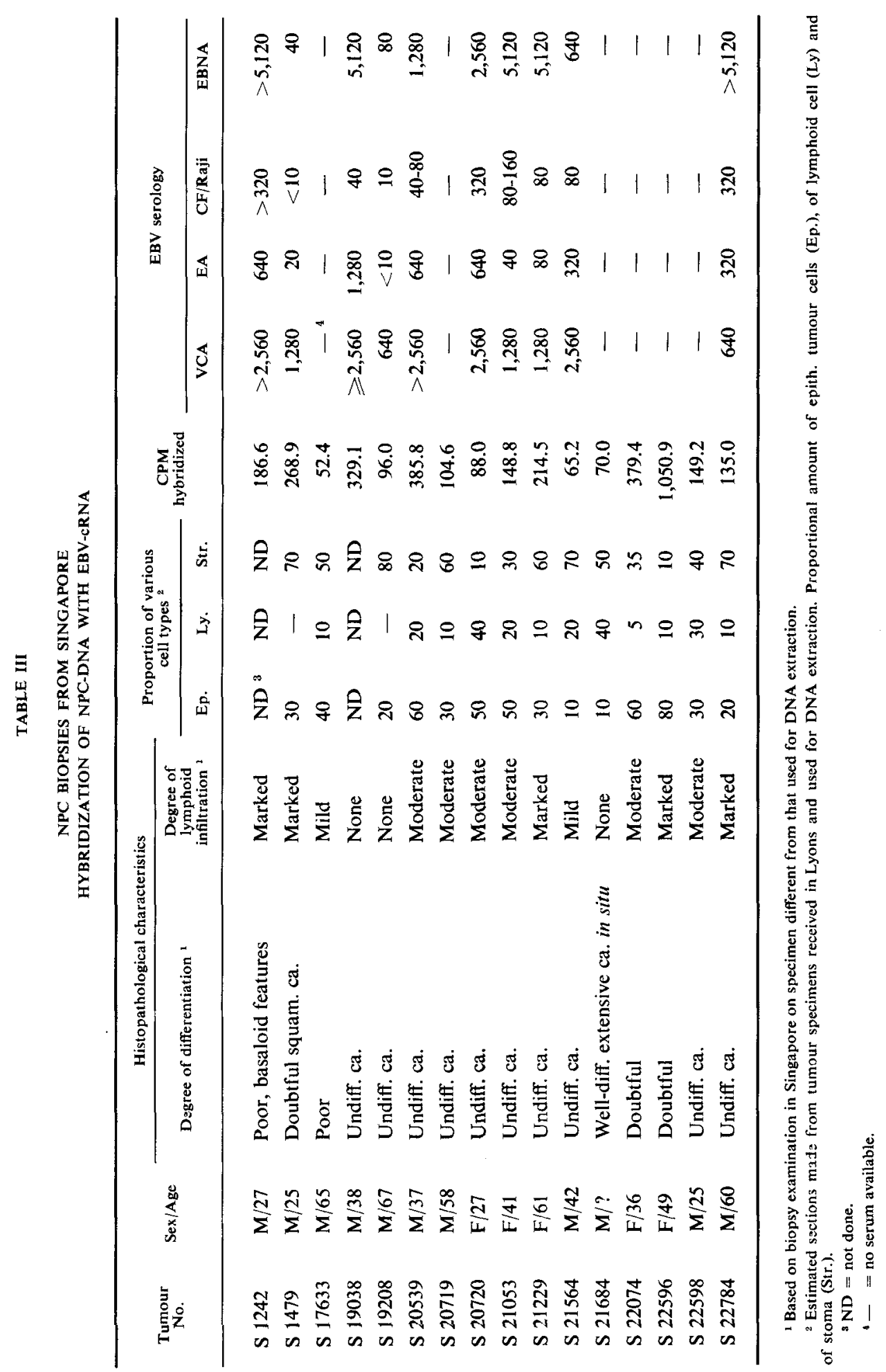


DESGRANGES ET AL.

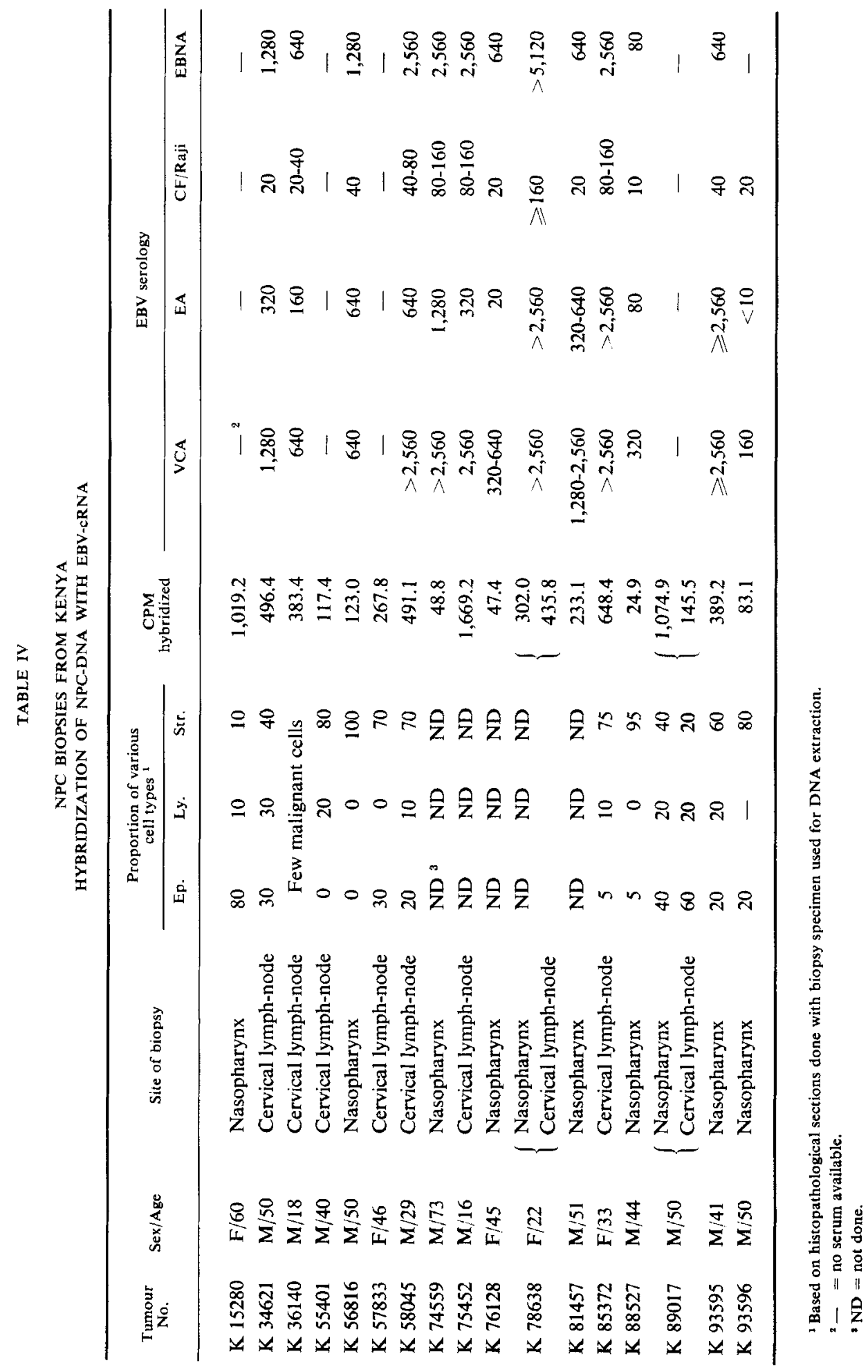


TABLE V

TUMOURS OTHER THAN NPC

HYBRIDIZATION OF DNA FROM TOTAL TUMOURS WITH EBV-CRNA

\begin{tabular}{|c|c|c|c|c|c|c|c|c|}
\hline \multirow{2}{*}{ Origin } & \multirow{2}{*}{$\begin{array}{c}\text { Reference } \\
\text { number }\end{array}$} & \multirow{2}{*}{ Sex/Age } & \multirow{2}{*}{$\begin{array}{l}\text { Histological } \\
\text { characteristics }\end{array}$} & \multirow{2}{*}{$\begin{array}{c}\text { CPM } \\
\text { hybridized }\end{array}$} & \multicolumn{4}{|c|}{ EBV serology } \\
\hline & & & & & $\mathrm{VCA}$ & EA & CF/Raji & EBNA \\
\hline Kenya & $\begin{array}{l}\text { K } 51321 \\
\text { K } 77905 \\
\text { K } 84825 \\
\text { K } 91339\end{array}$ & $\begin{array}{l}M / 35 \\
M / 63 \\
M / 45 \\
F / 28\end{array}$ & $\begin{array}{l}\text { Adenoid carcinoma } \\
\text { Hypopharynx carcinoma } \\
\text { Tumour of palate } \\
\text { Hypopharynx carcinoma }\end{array}$ & $\begin{array}{l}30.6 \\
47.0 \\
78.6 \\
82.9\end{array}$ & $\begin{array}{c}20-40 \\
\overline{640}^{3} \\
80\end{array}$ & $\begin{array}{l}<10 \\
<10 \\
<10\end{array}$ & $\begin{array}{l}10 \\
\frac{1}{<5} \\
10\end{array}$ & $\begin{array}{l}\frac{160}{320} \\
160\end{array}$ \\
\hline Tanzania & $\begin{array}{l}\text { T } 754 \\
\text { T } 757\end{array}$ & $\begin{array}{l}M / 12 \\
M / 6\end{array}$ & $\begin{array}{l}\text { Burkitt's lymphoma } \\
\text { Neuroblastoma }\end{array}$ & $\begin{array}{r}2,194.1 \\
72.3\end{array}$ & - & - & - & - \\
\hline Uganda & U 202 & $\mathrm{~F} / 5$ & Burkitt's lymphoma & 546.1 & 320 & 1,280 & 160 & 1,024 \\
\hline Tunisia & $\begin{array}{l}\text { Tu } 190 \\
\text { Tu } 227 \\
\text { Tu } 229 \\
\text { Tu } 230 \\
\text { Tu } 232 \\
\text { Tu } 288 \\
\text { Tu } 368 \\
\text { Tu } 403\end{array}$ & $\begin{array}{l}F / 65 \\
M / 25 \\
M / 71 \\
M / 57 \\
M / 54 \\
M / 38 \\
M / 53 \\
M / 15\end{array}$ & $\begin{array}{l}\text { Nasopharyngeal } \\
\text { lymphosarcoma } \\
\text { Nasopharynx } \\
\text { negative biopsy }{ }^{1} \\
\text { Plasmocytoma of } \\
\text { nasopharynx } \\
\text { Nasopharynx } \\
\text { negative biopsy }{ }^{1} \\
\text { Nasopharynx } \\
\text { negative biopsy }{ }^{2} \\
\text { Larynx carcinoma } \\
\text { Hodgkin's disease } \\
\text { Nasopharynx } \\
\text { negative biopsy }{ }^{2}\end{array}$ & $\begin{array}{r}52.1 \\
81.1 \\
158.7 \\
73.2 \\
\\
68.2 \\
114.8 \\
55.8 \\
32.1\end{array}$ & $\begin{array}{c}- \\
320 \\
320 \\
320 \\
320-640 \\
1,280-2,560 \\
-\end{array}$ & $\begin{array}{l}- \\
<10 \\
<10 \\
<10 \\
<10 \\
<10 \\
-\end{array}$ & $\begin{array}{l}- \\
\mathrm{AC} \\
16 \\
64 \\
\frac{\mathrm{AC}}{32} \\
-\end{array}$ & $\begin{array}{r}10 \\
320 \\
640 \\
80 \\
-512 \\
-\end{array}$ \\
\hline
\end{tabular}

${ }^{1}$ Cervical lymph-node biopsy showed presence of tuberculosis.

${ }^{2}$ Cervical lymph-node biopsy showed malignant metastasis from unknown primary tumour.

- = no serum available.

\section{DISCUSSION}

The above results confirm the presence of EBV DNA in epithelial tumour cells in nasopharyngeal carcinomas. They also show that the lymphoid cell preparations from NPC do not contain substantial amounts of EBV DNA.

In these experiments a relatively high proportion of NPC biopsies showed a low annealing rate. When we examined histopathologically a small piece of the tumour from which DNA was extracted, there existed a better correlation between the amount of carcinoma cells and the level of hybridization as compared to the histology of the same specimen used for diagnosis in the hospital. After separation, DNA from the epithelial cell preparation annealed at a signifcantly higher rate than DNA from the whole tumour. It is probable, therefore, that the stroma and lymphoid cells lowered the level of hybridization.

In NPC tumours, Yata et al. (1974) found regularly both $\mathrm{B}$ - and T-cells, but on the edge of the epithelial tumour cells mostly B-lymphocytes. In contrast, Jondal and Klein (1975) found that the vast majority of lymphocytes in NPC originate from the T-subpopulation. However, the markers for B- or T-cell populations were not the same in both studies and further clarification of the nature of the lymphoid cells close to the epithelial tumour cells is therefore needed.

The correlation between serological data and annealing rates of the corresponding tumour DNA did not reveal any outstanding association. Similarly, the comparison between hybridization level of undifferentiated and differentiated carci- 
nomas did not permit any conclusion, the number of well-differentiated tumours being very small. The comparative analysis of annealing rates of NPC tumours from the different geographical areas did not show significant differences, although there were relatively more tumours with high EBV DNA content from Kenya and Singapore than from Tunis.

This study has thus further established that no significant difference existed between NPC. originating from various geographical areas. The questions which now need to be urgently answered are whether normal nasopharyngeal epithelium is infected by EBV, and how the epithelial cells acquire the EBV genomes. Do epithelial cells have EBV receptors or are they infected by transfer of viral information from lymphoid cells? Electron microscopic evidence of loss of cell membrane continuity between epithelial and lymphoid cells in both normal mucosa and NPC
(Gazzolo et al., 1972; Vuillaume et al., 1973) would favour such a possibility. The studies of Glaser and Rapp (1972) on somatic cell hybrids should enlight this question; and our present aim is to obtain hybrids between epithelial tumorous cells from NPC and cells susceptible to EBV infection and transformation.

\section{ACKNOWLEDGEMENTS}

This work was performed in part under contract No. NO 1 CP 43296 within the Virus Cancer Program of the National Cancer Institute (USA), and supported by the Deutsche Forschungsgemeinschaft (SFB 118).

We wish to thank Mrs. M. C. Berthelon, Mrs. M. C. Favre and Mrs. M. F. Lavoué for serology and Mrs. C. Piccoli for her excellent technical assistance.

\section{CANCER DU RHINOPHARYNX. X. PRÉSENCE DE GÉNOMES EB DANS DES CELLULES ÉPITHÉLIALES SÉPARÉES PROVENANT DE TUMEURS OBSERVÉES CHEZ DES MALADES DE SINGAPOUR, DE TUNISIE ET DU KENYA}

Des biopsies de cancers du rhinopharynx en provenance de Singapour, de Tunisie et du Kenya ont été comparées, avant et après séparation des populations de cellules épithéliales tumorales et des cellules lymphocytaires, pour leur contenu en DNA viral EB, titré par hybridation du DNA cellulaire avec un RNA complémentaire viral. Dans tous les cas où la séparation des deux types cellulaires a été obtenue, les populations épithéliales contenaient plus de DNA viral que les populations lymphoides et que les tumeurs avant séparation. La présence de DNA viral semble donc être concentrée au niveau des cellules tumorales épithéliales. Par ailleurs, il n'a pas été observé de différences significatives entre les biopsies des différentes régions, quant à leur contenu en DNA viral.

\section{REFERENCES}

DE-ThÉ, G., Ablashi, D. V., Liabeuf, A., and Mourali, N., Nasopharyngeal carcinoma (NPC). VI. Presence of an EBV nuclear antigen in fresh tumour biopsies. Preliminary results. Biomedicine, 19, 349-352 (1973a).

DE-ThÉ, G., and GeSER, A., Nasopharyngeal carcinomas: recent studies and outlook for a viral etiology. Cancer Res., 34, 1196-1206 (1974).

DE-Thé, G., Sohier, R., Ho, J. H. C., and Freund, R., Nasopharyngeal carcinoma. IV. Evolution of complement-fixing antibodies during the course of the discase. Int. J. Cancer, 12, 368-377 (1973b).

Gazzolo, L., De-Thé, G., Vuillaume, M., and Ho, J. H. C., Nasopharyngeal carcinoma. II. Ultra- structure of normal mucosa tumor biopsies and subsequent epithelial growth in vitro. $J$. nat. Cancer inst., 48, 73-86 (1972).

Glaser, R., and RAPP, F., Rescue of the Epstein-Barr virus from somatic cell hybrids of Burkitt lymphoblastoid cells. J. Virol., 10, 288-296 (1972).

HeNle, G., and HENLE, W., Immunofluorescence in cells derived from Burkitt's lymphoma. J. Bact., 91, 1248-1256 (1966).

Henle, W., Henle, G., Zajac, B. A., Pearson, G., WAUBKe, R., and SCribA, M., Differential reactivity of human serums with early antigens induced by Epstein-Barr virus. Science, 169, 188-190 (1970). 
Huang, D. P., Ho, J. H. C., Henle, W., and Henle, G., Demonstration of Epstein-Barr virusassociated nuclear antigen in nasopharyngeal carcinoma cells from fresh biopsies. Int. J. Cancer, 14, 580-588 (1974).

JoNDAl, M., and KLEIN, G., Classification of lymphocytes in nasopharyngeal carcinoma (NPC) biopsies. Biomedicine, in press.

KLEIN, G., The Epstein-Barr virus, In: A. Kaplan (ed.), The herpesviruses, pp. 521-555, Academic Press, New York (1973).

Klein, G., Giovanella, B, C., lindahl, T., Fialkow, P. J., Singh, S., and Stehlin, J., Direct evidence for the presence of Epstein-Barr virus DNA and nuclear antigen in malignant epithelial cells from patients with anaplastic carcinoma of the nasopharynx. Proc. nat. Acad. Sci. (Wash.), 71, 4737-4741 (1974).

Nonoyama, M., Huang, C. H, Pagano, J. S., KleIN, G., and Singh, S., DNA of Epstein-Barr virus detected in tissue of Burkitt's lymphoma and nasopharyngeal carcinoma. Proc. nat. Acad. Sci. (Wash.), 70, 3265-3268 (1973).

Reedman, B. M., and Klein, G., Cellular localization of an Epstein-Barr virus (EBV) associated complement-fixing antigen in producer and nonproducer lymphoblastoid cell lines. Int. J. Cancer, 11, 499-520 (1973).

Vuillaume, M., and DE-ThÉ, G., Nasopharyngeal carcinoma. III. Ultrastructure of different growths leading to lymphoblastoid transformation in vitro. J. nat. Cancer Inst., 51, 67-80 (1973).

WOLF, H, ZUR HAUSEN, H., and Becker, V., EB viral genomes in epithelial nasopharyngeal carcinoma cells. Nature New Biol., 244, 245-247 (1973).
Wolf, H., zur Hausen, H., Klein, G., Becker, V., Henle, G., and Henle, W., Attempts to detect virus-specific DNA sequences in human tumours. III. Epstein-Barr viral DNA in non-lymphoid nasopharyngeal carcinoma cells. Med. Microbiol. Immunol., 161, 15-21 (1975).

Yata, J., Desgranges, C., De-Thé, G., and Mourali, N., Nasopharyngeal carcinoma. VII. B- and T-lymphocytes in the circulating blood and in tumour tissue. Biomedicine, 21, 244-250 (1974).

Yata, J., Desgranges, C., Tachibana, T., and DE-THÉ, G., Separation of human lymphocytes forming spontaneous rosettes with sheep erythrocytes. Biomedicine, 19, $475-478$ (1973).

zur Hausen, H., Diehl, V., Wolf, H., SchulteHolthausen, H., and Schneider, U., Occurrence of Epstein-Barr virus genome in human lymphoblastoid cell lines. Nature New Biol., 237, 189-190 (1972).

zur Hausen, H., and Schulte-Holthausen, H., Presence of EB virus nucleic acid homology in a virus-free line of Burkitt tumour cells. Nature (Lond.), 227, 245-248 (1970).

zur Hausen, H., Schulte-Holthausen, H., Klein, G., Henle, W., Henle, G., Clifford, P., and Santesson, L., EBV DNA in biopsies of Burkitt tumours and anaplastic carcinomas of the nasopharynx. Nature (Lond.), 228, 1056-1058 (1970).

zur Hausen, H., Schulte-Holthausen, H., Wolf, H., Dorries, K., and Egger, H., Attempts to detect virus-specific DNA in human tumours. II. Nucleic acid hybridizations with complementary RNA of human herpes group viruses. Int. J. Cancer, 13, 657-664 (1974). 